\begin{tabular}{|c|c|}
\hline DE GRUYTER & ECONOMIC THEMES (2014) 52 (3): 263-280 \\
\hline
\end{tabular}

\title{
COMMERCIAL DIPLOMACY IN SERBIA: CHARACTERISTICS AND AREAS FOR IMPROVEMENT
}

\author{
Slavica Penev \\ Institute of Economic Sciences, Belgrade, Serbia \\ $\square$ slavica.penev@ien.bg.ac.rs \\ Boštjan Udovič \\ Faculty of Social Sciences, University of Ljubljana, Slovenia \\ $\triangle$ bostjan.udovic@fdv.uni-lj.si \\ Mihajlo Đukić \\ Institute of Economic Sciences, Belgrade, Serbia \\ $\triangle$ mihajlo.djukic@ien.bg.ac.rs \\ UDC \\ 339.9 .012 \\ (497.11) \\ Original \\ scientific \\ paper

\begin{abstract}
The paper analyses the challenges of modern commercial diplomacy (CD), which became more relevant than it was in the pre crisis period. In this context, the authors analyzed the chronology of implementation of CD in Serbia, scope and efficiency of its activities, and the areas for improvement. Some of their findings, related to the efficiency and challenges in CDs activities, are based on the questionnaire conducted among 25 Serbian CDs. The paper concludes that in order to increase the efficiency of commercial diplomacy, coordination of the activities of the responsible institutions should be improved, to avoid overlapping in their work and to rationalize use of limited resources. However, the authors emphasised that the space for contribution of commercial diplomacy to the increase of export and FDI is insufficient, due to limited export potential and poor investment climate in Serbia. The authors conclude that in order to increase the efficiency of commercial diplomacy in export promotion area, it is important to implement the necessary reforms, which will result in the restructuring of Serbian economy, make it more competitive and export oriented. To increase the inflow of FDI to Serbia, it is necessary to create a
\end{abstract} \\ business friendly investment climate.
}

Received:

29.08.2014.

Accepted:

24.10.2014.
Key words: commercial diplomacy, export promotion, FDI, economic crisis, Serbia.

This paper is a part of research projects 47009 (European integrations and social and economic changes in the Serbian economy on the way to the EU) and 179015 (Challenges and prospects of structural changes in Serbia: Strategic directions for economic development and harmonization with EU requirements) financed by the Ministry of Education, Science and Technological development of the Republic of Serbia. 


\section{Introduction: Why, What and for Whom is Commercial Diplomacy?}

According to the classical, state-centered definition of diplomacy, the main task of diplomacy is to promote peaceful relations among states. However, in the 20th century, several new actors became part of the decision-making process within diplomacy. As a result, the classical definition widened, with the inclusion of non-state actors and an altered definition was provided describing diplomacy as a "peaceful cooperation among subjects in international community" (Brglez, 1998:61 and Udovič, 2009: 110). According to Saner and Yiu (2003: 12), new entrants to the diplomatic arena represent different groupings and organisations of local, national and international interests. These divergent forces co-exist with each other and exercise different forms of diplomatic influence to achieve their objectives. One view on the modern diplomacy, especially in the economic terms, can be that the modern diplomatic functions do not follow only the political issues, but complement the political issues with the economic ones. A typical representative for this is the economic diplomacy, whose primary task is to "increase (common) welfare through the expansion of national export and foreign direct investments". However, the view of the role of economic diplomacy is not so straightforward as it may seem. Firstly, because the concepts of economic, commercial, trade, business, corporate etc., diplomacy has not yet been addressed and adequately conceptualised, and secondly, because there is no clear distinction between all these concepts, especially in cases where the business society and state administration are strongly interconnected. However, the theoretical debates on economic diplomacy, which revived in the last decade, point out one division that has to be followed in the further debate in this article, i. e., the division between the state-led economic diplomacy and the business-led economic diplomacy. While the latter is often labelled as business or corporate diplomacy, the first is known as the concept of multilateral or bilateral economic diplomacy. While multilateral economic diplomacy deals mostly with the establishment of the international or global economic system (such as Brettowoods system), the bilateral economic diplomacy, labelled also as commercial diplomacy, is understood as the support of states to their enterprises' internationalisation.

After these tasks have been fulfilled, the state in cooperation with the national (economy) subjects has to develop the targeted tools and activities for each market, since there is no single instrument that can cover all the devoted markets, branches and industries. ${ }^{12}$

\footnotetext{
${ }^{1}$ Potter (2004: 55) defines commercial diplomacy, as the application of the tools of diplomacy to help bring about specific commercial gains through (i) promoting exports, (ii) attracting inward
} 
Although the main tasks of commercial diplomacy are linked to the trade promotion and promotion of foreign direct investments (FDIs), it should be noted that commercial diplomacy is not only an instrument of firms' internationalisation, but also an instrument that should attract FDIs to a country, ${ }^{3}$ increase competitiveness of domestic enterprises in the world market and help the domestic country to influence the international and global (concrete) economic activities. That is why it is often a myopic to understand commercial diplomacy only as an "export promotion agent". Having understood this, it is clear that commercial diplomacy goes far further than export and FDI promotion; it is present in the field of international trade, investments, tourism, country image, promotion of science \& technology etc. Commercial diplomacy, whether used accurately and strategically or otherwise, can in the modern times establish a country as a trademark and can develop even its intangibles. Since the modern economy is about intangibles, commercial diplomacy should be used as widely as possible. But the reality shows that instead of common activities of different state entities, commercial diplomacy is often understood as a battle-field for different state institutions, which replace cooperation and coordination with competition.

Regarding the commercial diplomacy structure, Rana (2000) presents five models of how commercial diplomacy can be performed: (i) unified model, where MFA completely handles and unifies the foreign affairs and the issues of foreign trade, (ii) partly unified model, where the MFA and the Ministry of Trade or Ministry of Economy jointly establish a special unit to handle trade and investments in the diplomatic mission, (iii) third agency model, where MFA stays completely out of the trade issues, which are to be handled by independent state entities under the supervision of the Ministry of Trade, (iv) competition model, where MFA and other ministries have overlapping tasks and responsibilities without clear divisions, and (v) renunciation model, where MFA completely handles the issues of foreign trade and investments over to other ministries, therefore MFA does not have any role in the economic work of the country.

The internal structure also reflects on the external structure of commercial diplomacy. In most cases the commercial diplomats (sometimes known also as economic/commercial attaches) are staff members of a diplomatic mission or

investment and preserving outward investment opportunities, (iii) the benefits of technological transfer and (iv) advocacy for national business community.

2 The concept of commercial diplomacy merges together two separate theoretical concepts: diplomacy and economy, both - as understood in the past - complementary means of foreign policy (Bayne and Woolcock, 2007).

${ }_{3}$ Promotion of trade is usually the first key goal, supplemented by promotion of inward investments, when around the 1970s, the mobilisation of FDIs became a priority for governments. Developing countries 'discovered' the importance of commercial diplomacy around this time, impelled in part by the urge to improve their trade earnings (Rana 2009: 6). 
heads of a "commercial representation" abroad with a diplomatic status. ${ }^{4}$ Certain business promotion tasks accomplished by commercial diplomats may also be assigned to non-diplomatic institutions, such as trade promotion organizations, chambers of commerce offices or consultants who work in cooperation with commercial diplomats or under their supervision. Over the past years, a practice has been developed that some countries without permanent diplomatic representation, opened an "economic treffpunkt", with a local personnel, able to promote and establish business opportunities between their "employing" and "the resident" country. The employment of locals brings two advantages: firstly, the sending/employing country lowers its costs and becomes cost-effective, and secondly, hiring a local - especially in psychographically distant cultures - offers more opportunities for domestic enterprises unable to cope with cultural and geographical distance. Since the employed person is a local, he/she is more familiar with local customs and particularities, which can offer an advantageous position for enterprises starting to operate in the selected market.

Sometimes in the debates the question on the relevance and appropriateness of commercial diplomacy is raised. Such questions especially tackle the issue "for what sort of countries commercial diplomacy remains relevant for". Even though it is quite hard to find a single answer on such complicated question, there are some points offering a partial answer on similar questions. Firstly, commercial diplomacy in the modern era of economic interdependence is relevant for all kinds of countries - small, large, developed underdeveloped, transition etc. As seen during the last crisis all states have, after the start of the crisis, employed the "state-machinery" to solve the economic problems. Lots of measures that were adopted were part of the commercial diplomacy milieu, and especially during the past six years commercial diplomacy has been developed in details, its activities were reformulated and improved, actions targeted. However, in the stable economic system, commercial diplomacy is more relevant (a) in transition states and in states where the political decision-makers can exert strong influence on the economic decisions/activities, or (b) in small states, which, being price-takers, can only marginally influence the world economic developments and have to adapt as soon as possible to the changes that occur in the international community. ${ }^{5}$ Wrapping up, it is possible to conclude that the commercial diplomacy is a condition sine qua non for the small transition economies as Serbia is.

Taking this point as a starting point we would like to present in this article the fait accompli of Serbia's commercial diplomacy, its main characteristics, issues, problems and 'remedies'. The intention of the article is therefore to

\footnotetext{
${ }^{4}$ There are also some examples when the diplomatic status is not granted to them.

${ }^{5}$ As pointed out by Naray (2008: 2) commercial diplomacy is extremely important for some small and middle-sized countries, whether they would like to survive in the age of enhanced globalization and competition (Naray, 2008: 2).
} 
present the outline and developments of Serbia's commercial diplomacy, especially in relation to the needs of business enterprises, while the last part of the article is devoted to debating some open issues and presenting some possible actions which should be done by the Serbian authorities to increase the competitiveness of the national commercial diplomacy and national economy.

The article is built of three interrelated parts. In the first part we describe in short the characteristics of commercial diplomacy in small (and transition) countries, while the second part deals with concrete issues of commercial diplomacy in Serbia, emphasising the strengths and weaknesses of the current system. In the last part we discuss the obtained results and conclude the article with some policy recommendations.

\section{Which Are the Challenges of the Modern Commercial Diplomacy?}

The recent economic crisis surfaced the question of state interventions, its role, and potential for its activities. This is a well-known problem, especially significant in small transition countries and resulting from their specific characteristics, which could be analysed from two different perspectives: the size and the issue of transition. The "size" issue tackles the difference between the price-setters and price-takers. While a small country has strong limitations in human in financial resources, its influence is lower compared to bigger countries. Since it is strongly embedded in the external (economic) environment, it is also more vulnerable. The aftermath is that a small country, because of the external factors, has to build-up its resilience to shocks coming from the international milieu. This can be achieved by strengthening its adaptive and absorption capacities. When doing so, a small country can use the external shocks as an opportunity and can become a free-rider within the changes of the international economic environment. While the size issue can be used as an advantage, the issue of being a country in transition is per definition a disadvantage (see Udovič: 2014). Being a transition country means that you have not settled the economic issues within your national economy, you have not dealt with the issue of competitiveness and you have not strengthened your economic potentials and marginalised the economic weaknesses. Being such a country means being more vulnerable, attentive to external shocks and economically and politically unstable. Finally, since your economy lacks competitiveness, your access to the global market is restrained. Taking all these into consideration it is clear that a well-established commercial diplomacy can be quite useful in overcoming the deficiencies of small and transition countries.

Before the crisis, commercial diplomacy was understood as less relevant, since the perspective was that it is a persistent activity of states for convincing other states to do or not to do something. At the time of the crisis, it became 
clear that commercial diplomacy is not only an activity required by states, but first and foremost an activity that is executed by the states and required by national enterprises that operate abroad (Ruëll and Zuidema, 2012). The development of the commercial diplomacy has become more intriguing in the time of the current economic crisis, when states use commercial diplomacy to mitigate the protectionist and interventionist policies of other governments. The main notion behind it is to establish a friendly environment for companies' internationalisation and exchange of goods and services. The economic crisis revealed the importance of cooperation between politics and economics. Commercial diplomacy on the one hand (reaction to the crisis) served as an accelerator of economic liberalisation, while on the other it served as a sort of support for the countries that faced economic and financial problems. As such, commercial diplomacy acted not only as a pushing factor, but also as a buffer (Justinek, 2010).

Even though commercial diplomacy is necessary both for large and small countries, there is a difference in its implementation. This means that small states as price-takers have to use commercial diplomacy strategically, consistently and pragmatically, while large states are not obliged to use commercial diplomacy for their survival, since their market allows them to economically survive also without strong ties with other subjects in the international environment. Comparing to small states, large states usually link their commercial diplomacy to their foreign (economic) activities, meaning that the economic interests are not separate from the political ones. This means that each foreign policy decision brings also the economic connotation (Udovič: 2014).

Despite of the certain advantages small countries have, in the context of their integration in global economic flows, their size could be also a weakness. For example, if a company operates in a small market, one could consider it as a big, even transnational. In a global market, it might be small or even irrelevant actor. Therefore, when entering the global market, a company has to be well prepared to protect itself from big international players. Small market may also imply resource scarcity, especially financial and human. For that reason, it is very important to have efficient resource management. This is particularly important in the field of commercial diplomacy. In that field, engaged staff have to be well educated, flexible, ready to adapt to changes in the environment and active in the process of searching for the new business opportunities.

The increasing complexity, unpredictability and rising risks require new policies and changes in the functioning of diplomacy and international business. Obviously, it is of primary importance to have certain knowledge and skill, but also to combine them in a proper way. The question is also whether skills should be similar for commercial diplomats and international businessmen, or if there is a divergence or convergence of required skills. 
The current economic crisis has once again highlighted the importance of political issues, which have been for some time in the background in terms of required competencies for the commercial diplomacy. The nature of the crisis problems (inequality, instability, risk, security challenges) is essentially political and require adequate policy responses. Haas (1999) says that the environment, both economists and diplomats are facing today is much more political. The state is firmly back on the economic scene in all countries. Businessmen face political problems which have to be properly managed. The question is whether the commercial diplomats adjust more to businessmen or vice versa. Before the crisis, the answer would be that commercial diplomacy has mainly required the competencies of businesses. With the crisis, things have changed, as the world is becoming more political, more uncertain and unpredictable. The social aspects are in the focus again (inequality, riots etc.). The importance of trust in the international business is becoming much more important compared to the previous period. Therefore, the commercial diplomats which are facing intense political/social issues need to observe more from a macro perspective, because the aforementioned issues have significant influence on the economy. This means that commercial diplomacy has to adopt rapidly the competencies and mind-set of businessmen. We need to know how the sources of competitive advantage could be modified and how to respond quickly and effectively on a global level. It is necessary to be able to predict events, comprehensively interpret trends and warn the businessman on future political, economic and security risks. The key to the success in commercial diplomacy is a system which does not produce post-mortem analyses that indicate why the outcome was negative, but rather pre-mortem ensuring that the bad outcome does not happen at all, or at least trying to mitigate shocks and damages.

Dislocation of the sources of economic growth to the East increases the importance of understanding cultural differences. In a multicultural environment, it is necessary to have people who are familiar with the specific skills (Beamish and Killing, 2001). Such skills include: ability to develop and implement strategic skills, change management and management of cultural diversities, functioning in a flexible organizational structure and teams, ability to establish communication, to teach and spread the knowledge within the organization. Especially important capabilities are international negotiation, innovativeness and international marketing capabilities (see Knight and Kim, 2009). The research focused on staffing solutions in the company's management found that weakest skills are in the field of intercultural sensitivity, initiating changes and leadership. The task of commercial diplomacy, among other things, is to convince economists of the great importance of cultural differences. In addition, a large number of actors, thereby complicate the issue of security of international action in terms of increasing pluralism of actors. Internet and information society generate certain weaknesses (breaking ties, the destruction of the database, unauthorised access). To a large extent, we face the danger of 
cyber conflicts and the need for safeguards at the firm and state level (Svetličič, 2013). At the same time the role of the media is becoming more and more important.

All of the above requires new knowledge and skills for both diplomats and businessmen. Obviously, there is a convergence of skills in both professions. For diplomats, it means that they have the skills of business people while businessmen are requiring competences of diplomats. However, there is still a predominant opinion that commercial diplomats have to learn and adopt skills of a businessman than vice versa.

If new knowledge and skills are required, in situations where competitiveness is highly dependent on prompt and adequate adaptation to constantly changing environment, education system has also to be reformed, as well as the methods of training for business leaders and commercial diplomats. The basic characteristic of the old system is specialised knowledge that is complemented by general interdisciplinary education/training. Diplomats abroad and business people from small countries and companies have to possess a broad knowledge and skills to be able to cope with the challenges of the changing international environment (Ruël and Zuidema, 2012). They must negotiate in their host country and negotiate with the unions, decide about agreements, to calm union conflicts, communicate with the public in order to address legal, financial, trade and development issues, foster relationships with employees, resolve disputes, and many others. Highly specialized expert cannot in all of these activities act as an individual. Sometimes a wider range of knowledge is necessary, at least consultation with colleagues or external experts. In addition, there are numerous so-called soft skills that are often underestimated, but are becoming increasingly important or even decisive precondition for the use of »hard skills«. In order to achieve better results it is necessary to acquire knowledge of the general skills of communication and negotiation as well as knowledge of cultural diversity management. The second challenge, more important in the short term, is the selection of personnel for work abroad, people who will effectively deal with cultural shock on their missions abroad. The first mistake that is made is relying exclusively on professional criteria and experience. It often happens that those who were very successful in their own country are quickly defeated abroad. This happens not only because of the inability to adapt to the new environment, but also due to the fact that some might become successful in their own countries because of the specific "connection" that does not exist abroad. The second mistake is insufficient preparation for working abroad. 


\section{Commercial Diplomacy in Serbia: Facts, Figures and Challenges}

\section{a. A Historical Outline and Structural Performance of Serbian Commercial Diplomacy.}

Early development of commercial diplomacy in Serbia can be found in three official documents which have been adopted in the 1970s in the former Yugoslavia - Law on the establishment of foreign companies (OG SFRY 39/1972), Law amending the Law on the establishment of foreign companies (OG SFRY 17/1973) and the Federal Constitution. According to the Federal Constitution, republics were given the authority to participate in the creation of a common foreign policy. During the '80s, when Yugoslavia fell into crisis, commercial diplomacy was raised to a higher level, since the Yugoslav economic recovery needed support of other countries and international organizations. One of the particularly noteworthy is the IMF and related standby agreements.

Political turbulences during the mid-1980s had also an impact on the economic structure of the Yugoslav Republics. Therefore, companies and banks (and subsequently the Republics) from different federal entities began to act independently in foreign markets by establishing their own "economic" offices (mostly known as bureaus). For example, they could form para-diplomatic institutions that performed their activities along with the diplomatic activities of the Federation. In June 1991 Slovenia and Croatia declared independence and Yugoslavia was disintegrated. In 1992, Serbia and Montenegro established the Federal Republic of Yugoslavia, which in 2003 became a state union of Serbia and Montenegro. After the dissolution of the Union of Serbia and Montenegro in 2006, Serbia became an independent country.

The development of commercial diplomacy in Serbia after the breakup of Yugoslavia was held under the influence of political specificities (conflicts in the region, sanctions on the Federal Republic of Yugoslavia etc.). As a consequence, the development of commercial diplomacy in Serbia during the 1990s was ad hoc. Since the economy was organised as a mixture of planned and market-economy with a significant state interventions, commercial diplomacy did not have an important position. After the democratic changes which took place at the end of 2000, Serbia accelerated the transition reforms, aiming to introduce a "classical" market economy. The Government established the Ministry for International Economic Relations and Serbian Investment and Export Promotion Agency (SIEPA), which was under the authorities of the Ministry. SIEPA has been the leading institution for the implementation of commercial diplomacy in Serbia. Main tasks were related to administrative activities of bilateral and multilateral economic cooperation in the context of FDI attraction, export promotion, administrative activities related to 
international donations, integration with the international economic organisations such as the WTO (World Trade Organisation) and CEFTA (Central European Free Trade Agreement) and improvement of Serbian image in the world. In the meanwhile, the Ministry of Foreign Affairs performed commercial diplomacy through the relatively undeveloped network of economic attaches, being a result of the lack of consistent strategies of commercial diplomacy. When in 2008 the new concept of Serbian commercial diplomacy was adopted, the commercial attaches (sent by the MFA) were recalled.

The new concept started with the signing of an Agreement between the Ministry of Economy and Regional Development and the Ministry of Foreign Affairs, in September 2008. That is the period when the commercial diplomacy was, for the first time, institutionally recognized as becoming one of the priorities of Serbian foreign policy. After that, the authorities and responsibilities of commercial diplomacy were transferred to the Ministry of Economy and Regional Development, establishing what Rana (2000) calls a "unified model of shared responsibility of two ministries" between the Ministry of Foreign Affairs and the Ministry of Economy and Regional Development. In addition, their powers are partly divided with SIEPA - Serbian investment and export promotion agency, and Serbian Chamber of Commerce, which has International offices in six countries: Russia - Moscow, Belgium - Brussels, France - Paris, Italy - Milan, Germany - Frankfurt and Austria - Vienna.

The public tender for the selection of 27 commercial diplomats was finalised in the second half of 2009. After the finalization of their trainings, during the first half of 2010, diplomats were sent to their destinations. 17 commercial diplomats were sent to the EU countries, out of which three in Germany and two in Italy, 5 to the regional centres of the former Yugoslavia, and 5 to the global centres (Russia, USA, Japan, China and Canada). After two years, the Government decided to recall the commercial attaches from all exYugoslav republics, and from Hungary and Ukraine. ${ }^{6}$

As commercial diplomats came from the Ministry of Foreign and Internal Trade and Telecommunications ${ }^{7}$, and not from the Ministry of Foreign Affairs, they just had scarce experience in the diplomatic practice. ${ }^{8}$ This was also an issue that was pointed out by some of them, since they were not part of the MFA structure, they not only had limited knowledge of how things were going on in diplomacy, but they were also not included holistically in the workload of the embassies. As such, they were always treated differently compared to their colleagues coming to the MFA.

\footnotetext{
6 The reason for this measure has been presented that the Government had to recall all commercial attaches from the region lied in austerity measures, introduced in 2011.

${ }^{7}$ In October 2012 Ministry of Economy and Regional Development was abolished, and commercial diplomacy became part of the Ministry of Foreign and Internal Trade and Telecommunications.

${ }^{8}$ They came mostly from parastate institutions and private companies.
} 


\subsection{Serbian Commercial Diplomacy in Practice: Past Problems and Future Challenges}

The main activities of Serbian commercial diplomats are related to the (i) trade promotion, focused not only on the increase of Serbian exports, but also on the search for new potential markets, and (ii) Foreign Direct Investment promotion, focused on the attraction of FDI to Serbia.

The distribution of the working time spent on different tasks, according to the responses to the questionnaire, conducted among 25 Serbian commercial advisors, 9 (Figure 1) indicates that most of the time (50\%) is spent on the "work in the field, search of partners". Much less time is spent on negotiations with the companies from Serbia (13\%), indicating that they can be considered as very inactive in their requirements to commercial diplomats. According to the survey, administrative work consumes $19 \%$ of their working time, while negotiations with local and state authorities therefore consume $7 \%$ and $11 \%$.

Figure 1. Percentage of Working Time of Serbian Commercial Diplomats Spent on Different Tasks

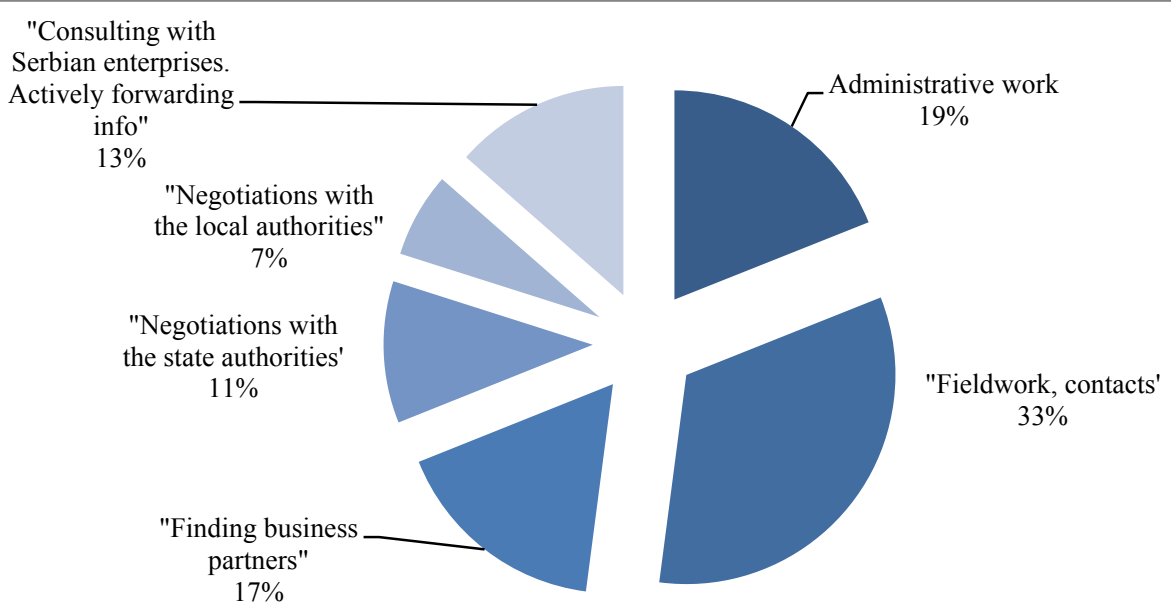

Source: Own calculation, based on the responses of Serbian commercial diplomats to the questionnaire.

\footnotetext{
9 The questionnaire was anonymous, and all the results appeared in an aggregated form. The response rate was $93 \%$. On that basis, we may conclude that the answers are representative and the findings might be used for generalization of the activities of economic diplomacy
} 
According to the same survey, answers of the commercial diplomats related to the time which they dedicate to their tasks (Figure 2), they spend much more time helping Serbian companies to resolve problems than supporting them in establishing business abroad, as Serbian companies are seeking help mostly when problems accrue in their work. The respondents also estimated their administrative work as time consuming.

Figure 2. Time Dedicated to the Tasks of Commercial Diplomats (1 = too little, 7 = Really too much)

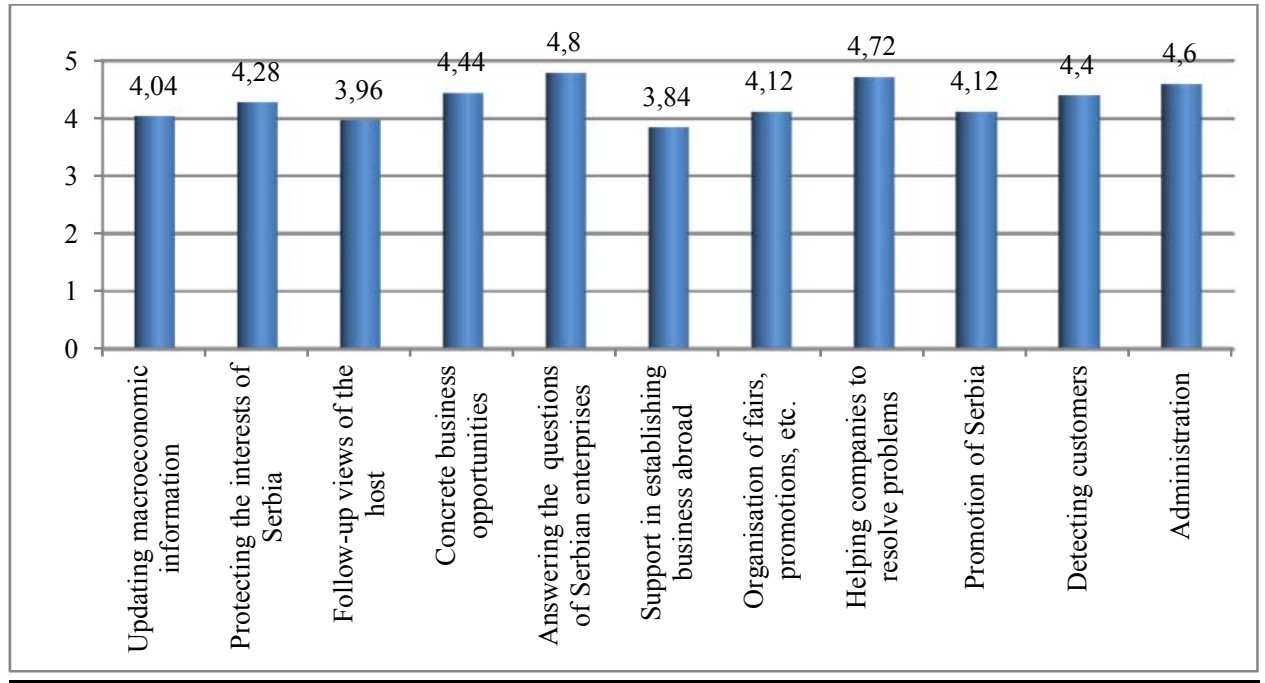

Source: Own calculation, based on the responses of Serbian commercial diplomats to the questionnaire.

Figure 3 shows the basic information and assessments of the respondents on the characteristics of corporate activities in the markets in which Serbia performs commercial diplomacy. According to the survey, SMEs consults commercial diplomats more frequently than large firms' representatives. There is not one recipe how commercial diplomacy should be performed, but the issue lies always in its application. That is why commercial diplomacy (and its activities) should be differentiated, segmented and applied to the needs of concrete enterprises. This means that $\mathrm{CD}$ has to help the large enterprises in their internationalisation, but at the same time it should be prepared to help the SMEs. All in all, commercial diplomacy should not be a sort of all-in-fits, but more a tailor-made activity, differing from time-to-time and form branch-tobranch (and of course state-to-state).

The survey also shows that companies are more frequently consulting CDs when they have problems conducting their activities in the foreign market, than before entering it. The survey indicates that Serbian companies very often 
neglect the importance of culture, language and business environment of the foreign markets, which might negatively affect their business activities.

The survey indicates that the enterprises do not have a business plan for their internationalisation. The absence of the plan can be also a hindering factor for the internationalisation and here commercial diplomacy cannot help much.

Figure 3: Performances of Serbian Enterprises in Selected Markets, (1 = too little, 7 = Really Too much)

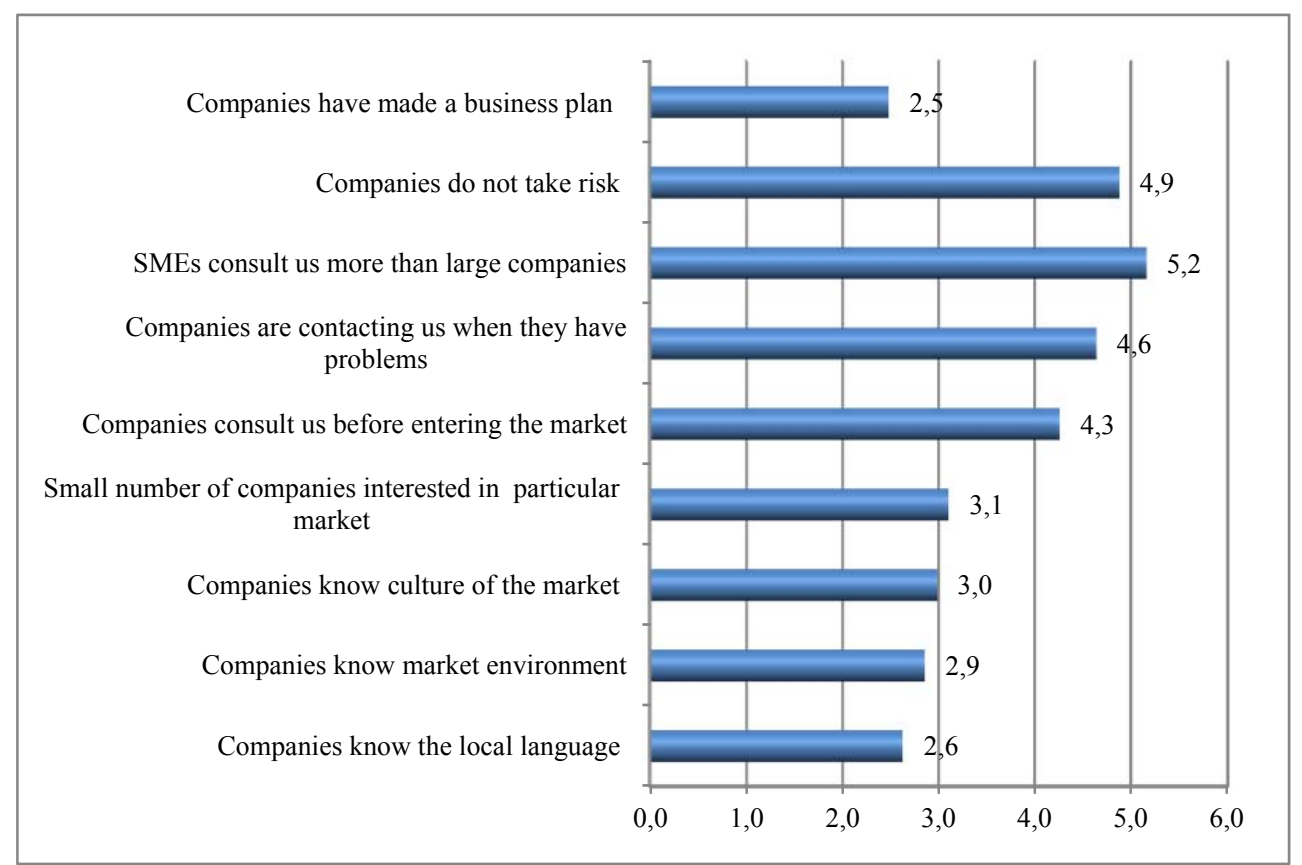

Source: Own calculation, based on the responses of Serbian commercial diplomats to the questionnaire.

According to the findings of the questionnaire, cooperation with the diplomatic representatives of the embassies, including the ambassadors, was relatively good, and the mutual activities were easily conducted. However, some commercial diplomats had difficulties due to poor cooperation with the embassy staff. The survey also indicates that financial resources were occasionally limiting factor for conducting their activities.

The selection of the countries where CDs were sent was twofold. The CDs were sent not only to the countries that are the main export markets for Serbian products and services, and the most important investors in Serbia, but also to countries that are potential export markets, and to major investing countries on the global level. 
Seventeen CDs were sent to the EU countries, the main export market of Serbia, since more than $60 \%$ of Serbian export is destined for the EU single market, and 78\% FDI in Serbia originate from the same region (Figure 4 and Figure 5). The high level of Serbian export to the EU market is additionally stimulated by EU trade preferences and the prospects of EU membership for Serbia. Its growth can be expected in the forthcoming period.

Figure 4: Serbian Export per Region, 2007-2013, in \% of Total

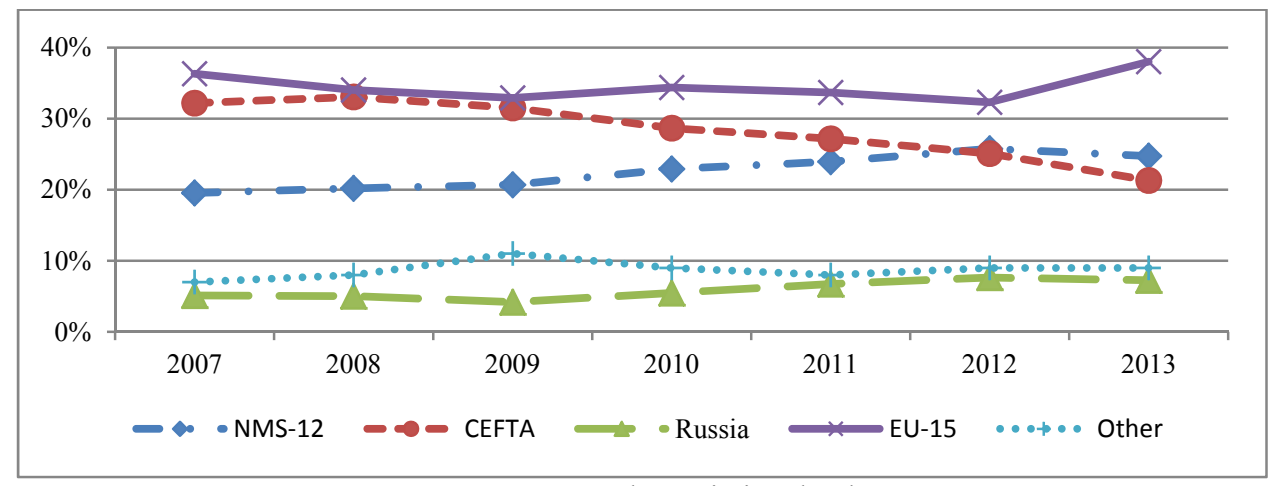

Source: UN comtrade statistics database

The Serbian Government sent 2 CDs to Italy and 3 CDs to Germany, as they are Serbia's most important trading partners. $28 \%$ of Serbian exports are aimed at these two markets, and almost $20 \%$ of FDI stock to Serbia originates from there (Figure 7).

Figure 5: Serbian Most Important Export Destinations, 2008 and 2013, in \% of Total

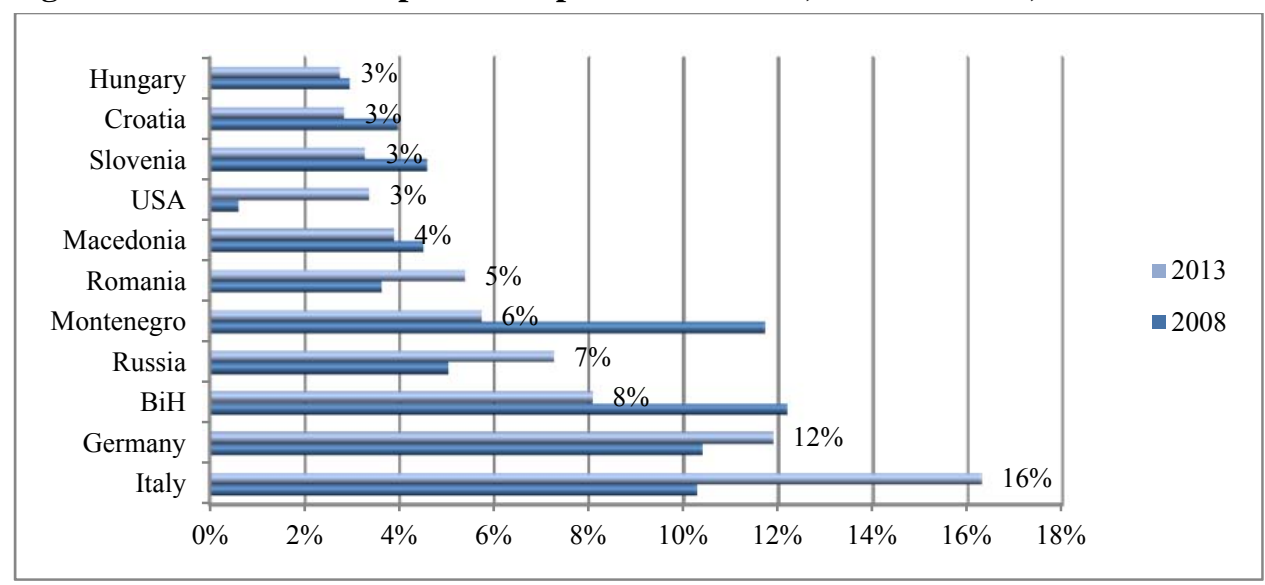

Source: UN comtrade statistics database 
On the other hand, even though the Netherlands, Norway and Luxembourg are among the main investing countries in Serbia (amounting to $27 \%$ of Serbian FDI stock) (Figure 7), there were no CDs allocated in these countries. Instead, the Netherlands and Luxembourg are under the authority of Serbian CD located in Belgium, while Norway is under the authority of CD located in Sweden. One of the reasons for this is the fact that most of their FDI to Serbia were related to several big privatization deals, and that these countries are not recognized as potentially important destinations for Serbian export.

Figure 6: Inward FDI Stock in Serbia by Region, 2013, in \% of Total

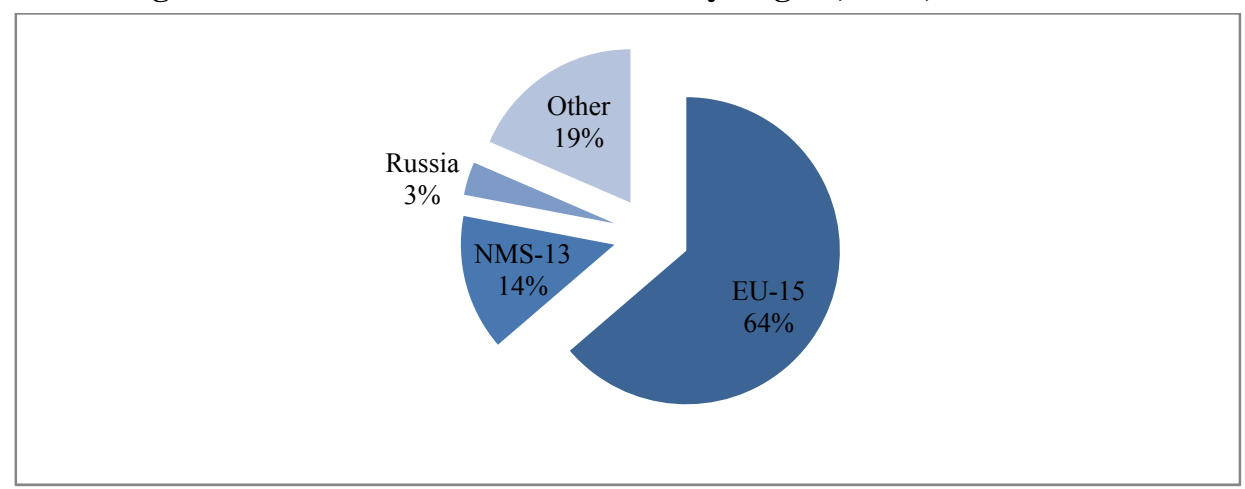

Source: WIIW FDI Report, Central, East and Southeast Europe, 2014

The Serbian Government initially sent 5 CDs to CEFTA countries and 6 to new EU member states. Romania, Slovenia and Hungary are the most important Serbian export destinations among the new EU member states. CEFTA countries are also important export destinations for Serbian exports, but their share in total Serbian exports is continuously declining, from 33\% in 2008 to only $21 \%$ in 2013 (Figure 4). In spite of the importance of most of these countries, in 2012 Serbian Government decided to recall the CDs from Slovenia and Hungary, CEFTA countries and Ukraine, due to the austerity measures introduced in 2011.

Serbian exports to Russia recorded permanent growth in the past few years, amounting to 7\% of total Serbian exports in 2013 (Figure 4). Though Russia is still not an important investor in Serbia (Russia has only one big investment in the Serbian energy sector), there is a huge space for further growth of experts to this market, and FDI inflow to Serbia.

China, Japan and Canada, where Serbian CDs were sent in 2009, can be considered as potential Serbian export markets, as less than $1 \%$ of total Serbian exports in 2013 is destined to these countries. These countries can be also important investors in Serbia, even though FDI inflows from these countries to Serbia are minimal. Even Serbian exports to the USA achieved around 3\% of its 
total exports, and USA FDI amount to $1.6 \%$ of Serbia's total FDI stock, there is a huge space for the improvement of the economic cooperation between these two countries.

Figure 7 : Inward FDI Stock in Serbia by Home Countries, 2008 and 2013, in \% of Total

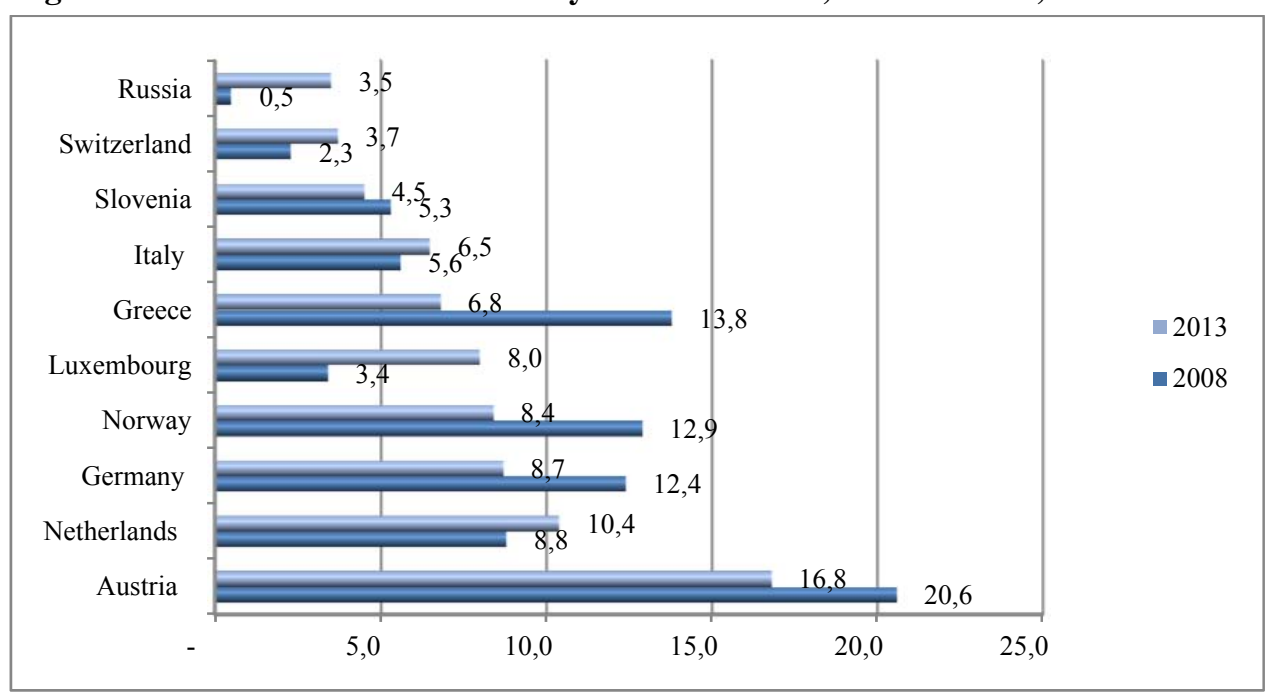

Source: WIIW FDI Report, Central, East and Southeast Europe, 2014 and 2010.

\section{Conclusions and Recommendations}

The Serbian Government is still in the process of searching for the optimal model of commercial diplomacy. However, in order to increase the efficiency of the existing, so-called shared model of commercial diplomacy, it is necessary to improve the coordination of the activities of the responsible institutions, with the aim to avoid overlapping in their work and to rationalize the use of limited resources. Further integration of CDs in the work of the embassies where they are located, and better cooperation with the diplomatic staff, would positively influence the efficiency of CDs.

Limited financial and other resources necessary for the work of $\mathrm{CD}$, are a serious limiting factor, which strongly affects their work. In spite of the limited capacity of the state budget, it would be recommendable to provide the level of funding that will enable the smooth operation of CDs.

It is more important for the CDs to focus on the development of new export markets than on expanding the existing ones, and to attract the investments from the investing countries which are still not present in Serbia. As some new countries and regions are gaining in economic importance, it would be recommendable to 
consider sending CDs to these economically expanding countries with the aim to promote Serbian exports and attract their investment to Serbia.

In spite of the importance of trade and investment promotion, the space for contribution of commercial diplomacy for the increase of export and FDI is insufficient, due to the limited export potential and poor investment climate in Serbia. Competitiveness of Serbian economy is low, with small and undiversified export potential, which limits the space for action of Serbian commercial diplomats. Poor quality of Serbian investment climate is a serious impediment for the inflow of FDI. In order to increase the efficiency of commercial diplomacy in export promotion area, it is important to implement the necessary reforms, which will result in the restructuring of Serbian economy in order to make it more competitive and export oriented. To increase the inflow of FDI to Serbia, it is necessary to create a business friendly investment climate.

\section{References}

Bayne, N. and Woolcock, S. (2011) The New Economic Diplomacy: Decision-making and Negotiation in International Economic Relations, $3^{\text {rd }}$ ed. Ashgate

Beamish, P., W. and Killing, P.J. (2001) "Global Strategic Alliances", in Tung, V.R., (ed.) The IEBM Handbook of International Business, Cambridge: Thomson Learning, pp. $164-182$

Brglez, M. (1998) "Kodifikacija sodobnega diplomatskega prava“, in Jazbec, M. (ed.), Diplomacija in Slovenci. Drava, Celovec, pp. 39-58.

Haas, R.N. (1999) The Bureaucratic Entrepreneur: How to Be Effective in Any Unruly Organization, Washington, DC: Brookings Institute Press

Justinek, G. (2010) Model ekonomske diplomacije Slovenije, Doktorska disertacija, Ekonomsko-poslovna fakulteta, Maribor.

Naray, O. (2008) "Commercial Diplomacy: A Conceptual Overview", Conference Paper, 7th World Conference of TPOs - The Hague, the Netherlands

Potter, E. (2004) "Branding Canada: The Renaissance of Canada's Commercial Diplomacy”, International Studies Perspectives, Volume 5, Issue 1, pp. 55-60.

Rana, K. S. (2000) Inside Diplomacy, Manas, New Delhi.

Rana, S.K. and Chatterjee, B. (2009) "The Role of Embassies", in Economic Diplomacy: India's Experience, pp. 3-25, http://www.cuts-international.org/Book_EconomicDiplomacy.htm

Ruëll, H. and Zuidema, L. (2012) "The Effectiveness of Commercial Diplomacy" A Survey Among Dutch Embassies and Consulates. Discussion Paper in Diplomacy. Netherlands Institute for International Relations Clingendael.

Saner, R. and Yui, L. (2003) International Economic Diplomacy: Mutations in Postmodern Times. Netherlands Institute of International Relations Clingendael, The Hague. 
Svetličič, M. (2013) "Je deglobalizacija odgovor na svetovne tektonske spremembe in krizo"? in Slavko Splichal (ed.) Globalizacija v dobro ali zlo? Zbornik ob 80letnici akademika Zdravka Mlinarja. Ljubljana: SAZU.

Udovič, B. (2009) Ekonomska in gospodarska diplomacija. Ljubljana: Fakulteta za družbene vede.

Udovič, B. (2014) Editorial Int. J. Diplomacy and Economy, Special Issue: The Role and Changes in National Commercial Diplomacy in the Time of the (Current) Economic Crisis, Vol. X, No. Y, pp..1-7. Forthcoming

\section{EKONOMSKA DIPLOMATIJA U SRBIJI: KARAKTERISTIKE I MOGUĆNOSTI ZA UNAPREĐENJE}

Apstrakt: U ovom radu se analiziraju izazovi sa kojima se suočava moderna ekonomska diplomatija (KD), koja je postala u većoj meri relevantna u odnosu na period pre izbijanja krize. U tom kontekstu, autori su analizirali hronologiju sprovođenja ekonomske diplomatije u Srbiji, njene domete, efikasnost i mogućnosti za njeno unapređenje. Neki od nalaza koji se odnose na efikasnost i izazove KD u Srbiji bazirani su na upitniku koji je popunilo 25 srpskih ekonomskih diplomata. Zaključak ovog rada ukazuje na potrebu za poboljšanom koordinacijom aktivnosti pojedinih institucija kako bi se izbeglo preklapanje njihovog rada i racionalizovala upotreba ograničenih resursa u cilju povećanja efikasnosti KD. Ipak, autori su posebno istakli da je potencijalni doprinos KD rastu izvoza i stranim direktnim investicijama (SDI) nedovoljan imajući u vidu ograničene izvozne potencijale i lošu investicionu klimu u Srbiji. Autori zaključuju da je u cilju povećanja efikasnosti KD u domenu promocije izvoza važno usvojiti neophodne reforme koje bi rezultirale restrukturiranjem srpske ekonomije i učinile je konkurentnijom i izvozno orijentisanom. U cilju povećanja priliva SDI, potrebno je kreirati povoljnije poslovno okruženje.

Ključne reči: ekonomska diplomatija, promocija izvoza, SDI, ekonomska kriza, Srbija 